\title{
CLAP AND THE POX IN ENGLISH LITERATURE
}

By SiR D'ARCY POWER, K.B.E., F.R.C.S., Honorary Librarian, The Royal College of Surgeons of England

Gentlemen,-I make no apology for the title of this paper. "Clap" and "the pox" are words of ancient lineage and were in common use, even in polite society, until they were replaced by gonorrhœea and syphilis.

Gonorrhœa was used in its etymological sense from quite early times. It meant any genito-urinary discharge, from pus due to an abscess in the kidney to a leucorrhoa. Our early ancestors had not much trouble in naming the venereal diseases from which some of them suffered: Syphilis was not yet introduced and they had only to consider gonorrhœa and soft sores. "Chaudepisse" was the name given for many years to inflammation caused by the gonococcus, for it was well known to the upper classes who spoke Norman French, whilst their English servants called it the Brenning (burning). John Arderne, an English surgeon, writing about 1376 , devotes a chapter to the treatment of an "Evil that is called chaudepisse" and advises injections of lead lotion. He also tells in another place of "brenning of the urine in the yard withinforth for which oil of almonds put in with a syringe availeth much." He describes, too, how " the yard of a man or the wicket of a woman should be treated if they be brent with heat and great swelling, sometimes with huge sorrow and pricking and in other patients with fever and unrest."

He gives the case history of a patient with soft sores ending in a sloughing phagedæna. "The man's yard began to swell, after coit due," says Arderne, " to the falling of his own sperm whereof he suffered great grievousness of burning and acheing as men do that be so hurt. He was told by a lady to apply a plaster of boiled leeks and grease. This made him worse." John Arderne was called in " and the next day put the patient on a 
table and with a razor cut away all the dead and stinking flesh," applied quick-lime and the patient got well.

The words " chaudepisse" and " brenning" lingered on into the seventeenth century. Shakespeare says in " King Lear": "No heretic burned but wenches' suitors." Dromio, in the "Comedy of Errors" (iv. 3), concludes that because "Courtesans appear to men like angels of light and light is an effect of fire and fire will burn ergo light wenches will burn. Come not near her."

Gonorrhœa was employed occasionally at this time in its specific sense, but still with some confused memory of its etymology. Andrew Boorde, in his "Breviary of Health," writes in the I66th chapter (ed. I575) of the Gomory passio with a side heading, " The Gomer passio." "Gontorhea is the Greek word. In Latin it is named Profluvio somnis. The barbarous worde is named Gomerra passio, it is named so because Gomer and Sodome did sinke for such lyke matter, but this matter is not voluntary and they did it voluntarily." Boorde is using the term, therefore, to mean masturbation and nocturnal pollution. $\mathrm{He}$ recommends for treatment camphor, and opium and henbane in conserve of roses as medicine; lettuce, melon and purslane as diet. It is clear, therefore, that Andrew Boorde attached no definite significance to gonorrhœa as he used the word.

"Clap " replaced "chaudepisse" late in the sixteenth century, and the earliest quotation given in the "New English Dictionary" is dated I587. It is of obscure origin, but was found to be convenient and soon came into common use. Howell speaks of it in his letters "Ho-Elianæ " in I650, and Samuel Butler, thirteen years later, says of Hudibras :

He had such plenty as sufficed

To make some think him circumcised.

And truly so he was perhaps

Not as a proselyte but for claps (i. 64).

And in another place, detailing the power of love, he writes :

'Tis this that proudest Dame enamours

To spite the world and to disparage

Claps, issues, infancy and marriage (ii. 24I).

There are many passing references to the clap in English literature, but the condition was not thought I 06 
worthy of any lengthy consideration, for the disease was looked upon as a trivial complaint incidental to youth, and it was a common saying that

A clap in Spring

Is physic for a King.

Dr. John Rolleston, in a paper on the "Medical Interest of Casanova's Memoirs," published in Janus for the year I9I7, pointed out that between the ages of fourteen and forty-one Casanova acknowledges to eleven attacks of venereal disease, and that very likely he had many more. Four of the recorded attacks were probably gonorrhœa only, one of which was complicated by orchitis ; five were soft chancres ; one was syphilis and one was possibly herpes preputialis.

The treatment of venereal disease was lucrative. Quacks treated the acute and uncomplicated cases; surgeons dealt with the subsequent gleets and strictures, making large incomes even in our own times from the passing of catheters. The subsequent sterility must have had an effect on the social history of the nation. Many of the older and better class families died out as a result of the indiscretion of boys who were said euphemistically to be sowing their wild oats.

It was far otherwise with the pox, which, coming as a new disease at the end of the sixteenth century, was looked upon as a serious and deadly affection to be treated and if possible cured. But the treatment was often more deadly than the disease itself. A certain amount of moral reprobation attached to it which, curiously enough, does not seem to have been the case with clap. It had therefore considerable difficulty in securing a name. For many years it was disguised in England as Morbus Gallicus, or simply as Morbus, interchangeably with Lues or Lues Venerea, but ordinary persons spoke of it as "the pox," using the word just as the present generation uses "bloody," a mere interjection or an intensive adjective.

The Concordance shows that Shakespeare employs the word "pox" nineteen times, but only twice formally. In "Love's Labour's Lost," Rosaline, in a chaffing match, says :

"O, that your face were not so full of O's!" 
And Katherine replies :

$$
\text { "A pox of that jest" (v. ii. 46). }
$$

And again in "Pericles," where Pander, speaking of Marina, says :

"Now the pox upon her green sickness for me!"

And the Bawd answers:

"Faith, there's no way to be rid of it but by the way of the pox"

(iv. v. I4).

The two diseases had become hopelessly confused with each other in the minds of the public by I63I, and so remained for more than 200 years. Philip Massinger, in "The Emperor of the East," which was licensed on March IIth, I63I, makes the Empiric say (Act IV, Scene 4) of a conjuring Balsam in which the Emperor had faith : for ?"

“An excellent receipt, but does your Lordship know what 'tis good

PALEL : "I would be instructed."

SURGEON : "For the gonorrhœa or, if you would hear it in plain phrase, the Pox."

EMPIRIC: "If it cure his Lordship of that by the way, I hope, Sir, 'tis the better. My medicine serves for all things and the pox, Sir, though falsely named the sciatica or gout, is the more catholic sickness."

The Restoration dramatists made many of their plots turn upon venereal disease. Wycherley, in "The Country Wife," represents Horner as pretending to be impotent from the pox and enables him thereby to seduce the wives of his friends. Shadwell, in " The Humourist," assumes that the pox is a humour, not a disease. But I need not dwell upon the plays of this period. They have been considered recently and exhaustively by Dr. Herbert Silvette, of the Medical School of the University of Virginia (The Annals of Medical History, r937, Vol. 9, New Series, pp. 37I-394). What strikes one in reading them is the light-hearted manner in which the subject of venereal disease is approached. It is taken as a matter of course and implies no moral turpitude or social handicap. It was widely spread and was looked upon as an unlucky or foolish mischance. Mr. Pepys (September 2nd, I66I) writes in his Diary: "Mr. Pickering though he be a fool yet he keeps much company and will tell all he I 08 
knows and hears. . . . He tells me plainly of the vices of the Court and how the pox is so common there, and, as I hear on all hands, that it is as common as eating and drinking."

But we cannot afford to throw stones. The newspapers at the present time are full of divorce news. It may be that as we think there were few virtuous people in Stuart days, so our successors may equally think that there must have been few undivorced couples in this generation, and that the marriage vows were more honoured in the breach than in the observance by the majority of those now living, which is manifestly untrue.

Dryden, in his bitter attack upon Shaftesbury and on the dissenting and fanatical clergy of his day, says in "The Medal," published in I682:

Religion thou hast none; thy mercury

Has past through every sect, or theirs through thee,

But what thou givest that venom still remains

And the poxed nation feels thee in their brains,

What else inspires the tongue and swells the breasts

Of all thy bellowing renegado priests.

Things began to mend at the beginning of the eighteenth century. English writers took a more serious view of venereal disease, pointing to the physical rather than to the moral disabilities of the clap and pox, which by this time had become identical in the mind of the public. The Tatler ends an amusing paper on Artificial Noses, written jointly by Addison and Steele and dated December 7 th, I7Io (No. I60), with the advice :

"I shall close this Paper with an admonition to young men of the Town which I think the more necessary because I see several new fresh-coloured faces that have made their first appearance in it this winter. I must therefore assure them that the art of making noses is entirely lost, and, in the next place, beg them not to follow the example of our town-rakes who live as if there were a Taliacotius to be met with at the corner of every street. Whatever young men may think, the nose is a very becoming part of the face ; and a man makes a silly figure without it. But it is the nature of youth not to know the value of anything until they have lost it. The general precept, therefore, I would leave with them is to regard every town-woman as a particular kind of Syren that has a design upon their noses, and that amidst her 
flatteries and allurements they will fancy she speaks to them in that humourous phrase of Old Plautus, Ego tibi faciem denasabo mordicus, 'Keep your face out of my way, or I will bite off your nose.'

Daniel Defoe took up the story a few years later, applying it to women instead of men. He published in I722 "The Fortunes of Moll Flanders," who was born in Newgate, was twelve years a whore, five times a wife, twelve years a thief, and eight years a transported felon in Virginia." She was a queen of rogues, but it is impossible not to like her. She escaped both the clap and the pox, grew rich, lived honestly, and died a penitent at the age of sixty. Defoe takes occasion to point out the danger of promiscuous intercourse when he makes Moll Flanders say :

"There is nothing so absurd, so surfeiting, so ridiculous, as a man heated by wine in his head and a wicked lust in his inclination together; he is in the possession of two devils at once and can no more govern himself by his reason than a mill can grind without water. Vice tramples upon all that was in him that had any good in it ; nay, his very sense is blinded by its own rage and he acts absurdities even in his own view, such as drinking more when he is drunk already, picking up a common woman without any regard to what she is or who she is ; whether sound or rotten, clean or unclean; whether ugly or handsome, old or young. Such a man is worse than a lunatic.

"These are the men of whom Solomon says, "They go like an ox to the slaughter, till a dart strikes through their liver'; an admirable description, by the way, of the foul disease which is a poisonous deadly contagion mingling with the blood whose centre or fountain is the liver; from whence by the swift circulation of the whole mass that dreadful nauseous plague strikes immediately through his liver and his spirits are infected, his vitals stabbed through as with a dart."

Defoe continues his homily and Moll says: "As for me I would have sent him safe home to his house and to his family, for 'twas ten to one but he had an honest virtuous wife and tender innocent children that were anxious for his safety and would have been glad to have gotten him back home and taken care of him, till he was restored to himself and then with what shame and regret 
woúld he look back upon himself! How would he reproach himself with associating himself with a whore! picked up in the worst of all holes, the cloister [of the Priory church during St. Bartholomew's Fair in Smithfield], among the dirt and filth of the town! how would he be trembling for fear he had got the pox, for fear a dart had struck through his liver and hating himself every time he looked back upon the madness and brutality of his debauch! how would he, if he had any principles of honour, abhor the thought of giving any ill-distemper, if he had it, as for aught he knew he might, to his modest and virtuous wife and thereby sowing the contagion in the life-blood of his posterity.'

Smollett published " Roderick Random " in I748, and as an episode gives the history of Miss Williams (Chapters XXI and XXII). He tells that when his hero first met the lady " she found herself dangerously infected with a distemper to which all women of the town are particularly subject ; that her malady gaining ground every day she became loathsome to herself and offensive to others; that she had accordingly put herself into the hands of an advertising doctor, who, having fleeced her of all the money she had or could procure, left her in a worse condition than that in which he had found her." Smollett, too, points a moral to adorn this tale, but it is from the harlot's point of view. He says :

"Of all professions I pronounce that of the courtesan the most deplorable but, Miss Williams affirmed, that notwithstanding the disgrace which had fallen to her share, she had not been so unlucky in the condition of the prostitute as many others of the same community. I have often seen, said she, whilst I strolled about the streets at midnight, a number of naked wretches reduced to rags and filth, huddled together like swine, in the corner of a dark alley; some of whom, but eighteen months before, I had known the favourites of the town, rolling in affluence and glittering in all the pomp of equipage and dress. And indeed the gradation is easily conceived; the most fashionable woman of the town is as liable to contagion as one in a much humbler sphere; she infects her admirers; her situation is public; she is avoided, neglected, unable to support her usual appearance, which, however, she strives to maintain as long as possible; her credit fails, she is obliged to retrench and become a night- 
walker ; her malady gains ground; she tampers with her constitution and ruins it; her complexion fades; she grows nauseous to everybody; finds herself reduced to a starving condition; is tempted to pick pockets; is detected, committed to Newgate, where she remains in a miserable condition till she is discharged. Nobody will afford her lodging; the symptoms of her distemper have grown outrageous; she sues to be admitted into an hospital, where she is cured at the expense of her nose ; she is turned out naked into the streets, depends upon the addresses of the lowest class, is feign to allay the rage of hunger and cold with gin; degenerates into a brutal insensibility, rots and dies upon a dunghill."

Lord Chesterfield looks at the matter from the point of view of a man of the world without regard to any moral question. He writes a letter to his natural son, Philip Stanhope, which is dated November 8th (O.S.), I750, saying :

"You will easily perceive, that I mean to allow you whatever is necessary not only for the figure but for the pleasures of a gentleman and not to supply the profusion of a rake. This you must confess does not savour of either the severity or parcimony of old age. . . . Having mentioned the word Rake I must say a word or two more upon that subject because young people too frequently, and always fatally, are apt to mistake that character for that of a man of pleasure; whereas there are not in the world two characters more different. A rake is the composition of all the lowest, most ignoble, degrading, and shameful vices ; they all conspire to degrade his character and to ruin his fortune; while wine and the pox contend which shall soonest and most effectually ruin his constitution. A dissolute flagitious footman or porter makes full as good a rake as a man of the first quality. By the bye, let me tell you, that in the wildest part of my youth, I never was a rake, but on the contrary, always detested and despised the character.

"A man of pleasure, though not always so scrupulous as he should be, and, as one day he will wish to have been, refines at least his pleasures by taste, accompanies them with decency, and enjoys them with dignity. Few men can be men of pleasure ; every man may be a rake."

This, I think, is the end of venereal disease in litera- 
ture for many years. A new school of novelists came in with Fielding and Richardson. The lady novelists of the half century following them very properly ignored the subject; what the present generation writes about I do not know, for I have not read them. I am, however, quite sure that there is no allusion to venereal disease in the writings of Jane Austen, Miss Burney, or the Brontës. Clap and pox had become vulgar words and were replaced by gonorrhœa and syphilis. The whole subject of venereal disease had become tabu during the Victorian period, and for many years there was a conspiracy of silence. The disease was looked upon as a divine punishment for sexual immorality, and it is not mentioned either by Thackeray or Dickens.

Better counsels prevailed in our times. Ibsen wrote of it in "Ghosts," published in I88I, and ten years later Brieux in "Les Avariés," known to us as "Damaged Goods." They called attention in all seriousness to the disastrous effects of syphilis and thereby began to educate the public upon right lines. But this dragging venereal disease back into the light met with considerable opposition, and it was not until a still later period that its divine origin was abandoned. The discovery of the gonococcus and of the Spirochate pallidum ended the myth once and for all. The Government took the matter in hand in I9I4 and taught that prevention was better than cure. The cost of treatment was subsidised, and the walls of the public urinals are now placarded with directions about "Clap and the Pox," so that the old words have come back into common use. But these placards are in no sense literature, and the subject of my address is Venereal Disease in English Literature. 